\title{
Call for Submissions
}

\author{
Special Guest Edited Issue of Dance Research Journal
}

Guest Editors: Katharina Pewny, Annelies Van Assche, Simon Leenknegt, and Rebekah Kowal

\section{WORK WITH(OUT) BOUNDARIES: Precarity and Dance}

The work of dance is work without boundaries: first, the dance profession has become a transnational affair, with dance artists often in different countries with colleagues from different nationalities. This border mobility increases economic insecurity for performing artists because the differences between national social security systems cause problems of accessibility and portability of rights (Polácek 2007). In addition, the high mobility rate across borders often prevents professional dance artists from making the transition to a second career (IJdens et al. 2008). Secondly, in line with "the new spirit of capitalism" (Boltanski and Chiapello 2006), the dance artist performs immaterial labor on a flexible basis within the context of temporary project work. Due to the increasingly project-oriented and immaterial nature of the profession, it is difficult to determine the boundaries of where work or employment time ends and private life begins. We theorize that traces of these boundary-less working conditions can be found in the performances of dance artists today. For this special issue of Dance Research Journal, we invite submissions to explore this theme in relation to dance as work with(out) boundaries. Questions we might consider are: How do precarious work and labor regimes influence the artistic production of dance artists? What is the impact of working on a transnational and/or project-oriented basis on the professional lives of dance artists? What impact do public and private resources for the arts and austerity measures have in the making of dance pieces? How do different traditions, cultures or societies evaluate the idea of dance as labor? What geopolitical boundaries run across the international flow of dancers' bodies? How does the current political climate, in which geopolitical borders are increasingly being closed, affect the labor of mobile dance artists? (How) are dance styles and customs translated to other contexts and what is the role of post-, de- or neocolonial processes in this translational labor? Which (inter)disciplinary approaches and methodologies are useful to do research on dance as (precarious) work or practice?

Contributions addressing any of these issues and focusing on varying and specific historical and cultural moments and locales are welcome.

Final deadline for submissions: March 30, 2018

Approximate length: 6,000 words (not including notes and references)

Inquiries and submissions to: Simon Leenknegt (Simon.Leenknegt@ugent.be) or Annelies Van Assche (Annelies.VanAssche@ugent.be) 


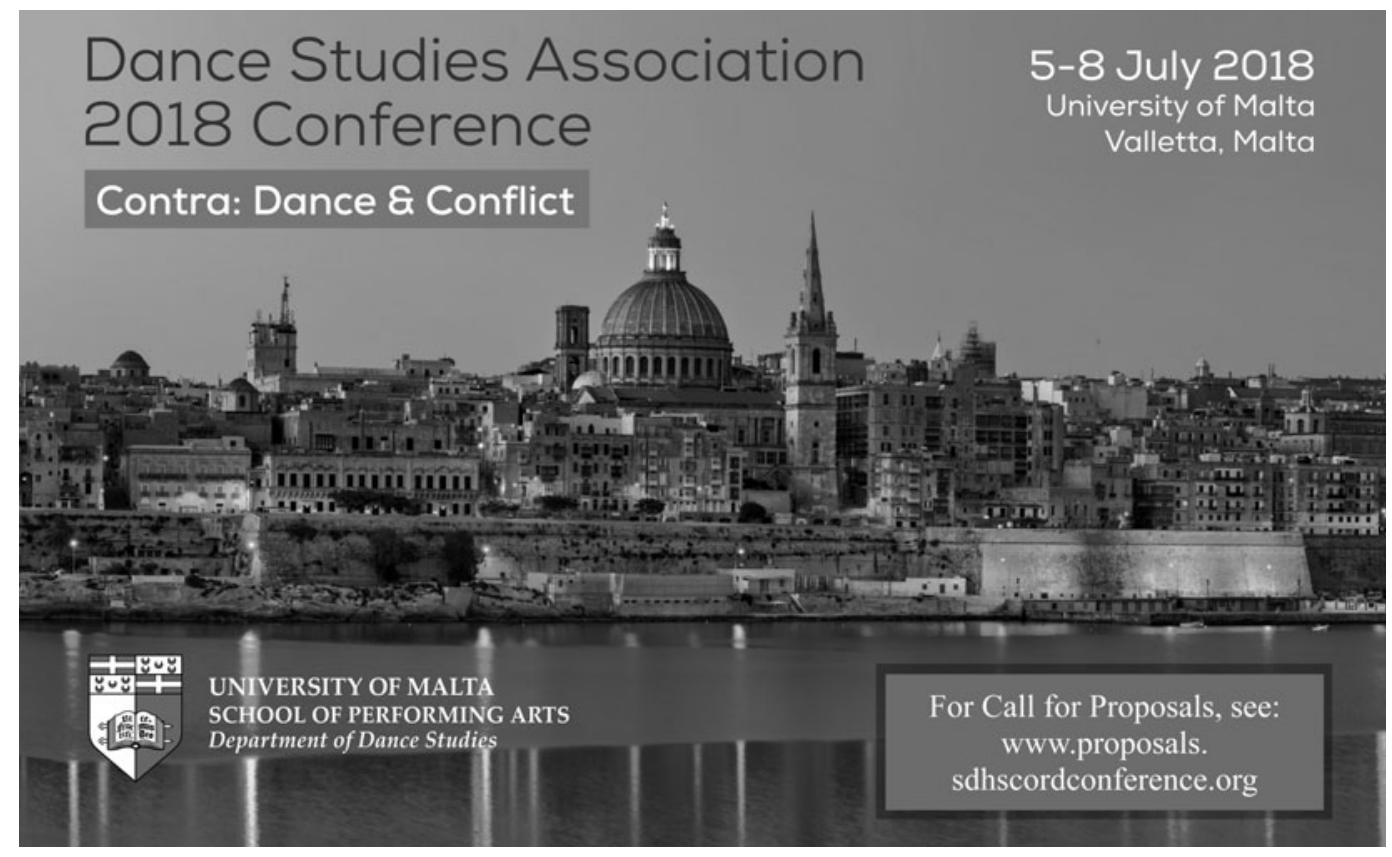


Dance Research Journal (DRJ) is indexed and abstracted by the following databases: Academic Search Elite, Academic Search Premier, Dance Collection Catalog of The New York Public Library, Expanded Academic Index, Humaities Index, Index to Dance Periodicals, International Index to Performing Arts, Proquest and SPORTDiscus. Complete articles are available on the Web through UMI. Past issues (through 2000) are indexed in the CD-ROM, Dance: Current Awareness Bulletin. Back issues of DRJ are available on JSTOR.

The Dance Studies Association (DSA) is an interdisciplinary organization with an open, international membership. Its purposes are I) to encourange research in all aspects of dance, including its related fields; 2) to foster the exchange of ideas, resources, and methodologies through publications, international and regional conferences, and workshops; 3 ) to promote the accessibility of research materials.

DSA is a nonprofit, tax-exempt organization. Copies of the DSA financial and operating report, filed with the state of New York, are availale upon written request from the New York State Board of Social Welfare, Charities Registration Section, Office Tower, Empire State Plaza, Albany, NY 12242.
After January 15, 2018, please see http://www.dancestudiesassociation.org for information about annual memberships in Dance Studies Association, which includes Dance Research Journal (3 issues per year), Studies in Dance History (one monograph per year), and Conversations Across the Field of Dance (one issue per year), in addition to other member benefits. Institutional subscription rates for 2017 are given below.

\begin{tabular}{|c|c|c|}
\hline & $\begin{array}{c}\text { North America } \\
\text { (USA, Canada, } \\
\text { Mexico) }\end{array}$ & $\begin{array}{l}\text { Outside } \\
\text { North } \\
\text { America }\end{array}$ \\
\hline $\begin{array}{l}\text { Institutions print } \\
\text { and electronic: }\end{array}$ & $\$ 246$ & $\mathfrak{E} 154$ \\
\hline $\begin{array}{l}\text { Institutions } \\
\text { electronic only: }\end{array}$ & $\$ 177$ & $\mathfrak{E} 110$ \\
\hline $\begin{array}{l}\text { Institutions print } \\
\text { only: }\end{array}$ & $\$ 223$ & $\mathfrak{E} 138$ \\
\hline $\begin{array}{l}\text { Association Paid } \\
\text { Member rate }\end{array}$ & $\mathfrak{E} / \$ 63$ & \\
\hline
\end{tabular}




\section{Dance Research JOURNAL}

Forthcoming Articles in DRJ 50/1 (April 2018)

Articles The Bennington Summer School of the Dance Oral History Project 1978-1979

Sanja L'Hotellier

An Enhanced Otherworldliness: Thierry De Mey's Screendance Based on William Forsythe's One Flat Thing, reproduced

Wesley Lim

Noa Eshkol and the Idea of a Chamber Dance Group

Sally Gardner

Choreographing American Dance Archives: Artist-Driven Archival Projects by Eiko \& Koma, Bebe Miller Company, and Jennifer Monson

Rosemary Candelario 